Taxonomy and systematics

\title{
Thermophile mats of microalgae growing on the woody structure of a cooling tower of a thermoelectric power plant in Central Mexico
}

\author{
Matas de microalgas termófilas que crecen sobre la estructura de madera de una torre \\ de enfriamiento de una central termoeléctrica en el centro de México \\ Yadiralia Covarrubias $^{\mathrm{a}}$, Enrique A. Cantoral-Uriza ${ }^{\mathrm{b}}$, J. Sergio Casas-Flores ${ }^{\mathrm{c}}$, \\ J. Viridiana García-Meza ${ }^{\text {a,* }}$ \\ ${ }^{a}$ Laboratorio de Geomicrobiología-Metalurgia, Universidad Autónoma de San Luis Potosí, Sierra Leona 550, Lomas 2da. Sec., 781210 San Luis Potosí, San Luis \\ Potosí, Mexico \\ ${ }^{\mathrm{b}}$ Laboratorio de Ecología Acuática y Algas, Unidad Multidisciplinaria de Docencia e Investigación, Facultad de Ciencias, Universidad Nacional Autónoma \\ de México, Campus Juriquilla, Boulevard Juriquilla 3001, 76230 Juriquilla, Querétaro, Mexico \\ ${ }^{c}$ División de Biología Molecular, Instituto Potosino de Investigación Científica y Tecnológica, Camino a la Presa San José 2055, Lomas 4ta. Sec., 78216 San Luis \\ Potosí, San Luis Potosí, Mexico
}

Received 21 January 2015; accepted 11 February 2016

Available online 13 May 2016

\begin{abstract}
The aims of this research are to identify and describe a periphyton community of thermophilic microalgae in order to expand our knowledge on biodiversity of a particular environment. Conspicuous biomass of thermophilic microalgae $\left(48^{\circ} \mathrm{C}\right)$ inhabits the cooling towers of the thermoelectric power plant of Villa de Reyes (Central Mexico). Aggregate samples or microalgal mats were taken in three different areas of the top of a cooling tower, for identification. According to the sequencing analysis of $16 \mathrm{~S}$ and 18S rDNA genes, the community is dominated by 3 species of Cyanoprokaryota: Chlorogloeopsis fritschii, Arthronema africanum and Chroococcidiopsis sp., previously reported as thermophiles. Also, 2 species of the Chlorophyte or green algae Scenedesmus. Finally, 12 species of diatoms comprise the microalgal community; diatoms were only microscopically identified within the mats, suggesting that the mats constitute a suitable microenvironment in thermal ambiences. The identified species are of particular interest because their habitat represents an extreme and an artificial biotope. To the best of our knowledge, this is the first report of thermophilic communities of microalgae in Mexico from a power plant; also, this is the first report of A. africanum for the country.

All Rights Reserved (C 2016 Universidad Nacional Autónoma de México, Instituto de Biología. This is an open access item distributed under the Creative Commons CC License BY-NC-ND 4.0.
\end{abstract}

Keywords: Microalgal mats; Thermophilic; Arthronema africanum; Diatoms; Mexico

\section{Resumen}

Esta investigación tiene por objetivo identificar y describir la comunidad perifítica de microalgas termófilas, para expandir nuestro conocimiento de la biodiversidad en ambientes particulares, como las microalgas termófilas $\left(48^{\circ} \mathrm{C}\right)$ que crecen de manera conspicua en la zona superior de la torre de enfriamiento de la central termoeléctrica de Villa de Reyes (centro de México). Se tomaron muestras de agregados o tapetes microalgales en 3 zonas distintas de la parte superior de una torre de enfriamiento, para su identificación. Una vez realizada la amplificación, la clonación y el análisis de los genes que codifican para las subunidades $16 \mathrm{~S}$ y $18 \mathrm{~S}$ del rDNA, se observó el predominio de 3 especies de Cyanoprokaryota: Chlorogloeopsis fritschii, Arthronema africanum y Chroococcidiopsis sp., especies descritas como termófilas en trabajos previos. Además, se identificaron 2 especies de Chlorophyta (algas verdes) del género Scenedesmus y 12 especies de diatomeas; la identificación de diatomeas se realizó a partir de observaciones por microscopia electrónica de barrido. Característicamente, las diatomeas solo se observaron dentro los densos tapetes algales que se conforman, sugiriendo que estos tapetes constituyen un microambiente conveniente en ambientes térmicos. Las especies

\footnotetext{
* Corresponding author.

E-mail address: jvgm@uaslp.mx (J.V. García-Meza).

Peer Review under the responsibility of Universidad Nacional Autónoma de México.
} 
identificadas son de particular interés, ya que su hábitat representa un biotopo extremo y artificial. Por lo que sabemos, este trabajo constituye el primer registro de microalgas termófilas que habitan en torres de enfriamiento y Arthronema africanum se documenta por primera vez para México. Derechos Reservados (C 2016 Universidad Nacional Autónoma de México, Instituto de Biología. Este es un artículo de acceso abierto distribuido bajo los términos de la Licencia Creative Commons CC BY-NC-ND 4.0.

Palabras clave: Tapetes microalgales; Termofilia; Arthronema africanum; Diatomeas; México

\section{Introduction}

The importance of expanding our knowledge on biodiversity and identifying and characterizing microorganisms, from extreme environments, responds to the social, scientific and technological requirements worldwide (Connolly et al., 2011). This knowledge could serve to develop new and sustainable technologies to obtain food, nutritional supplements, medicines, biofuels, fibers, biopolymers, colorants or other biomaterial, and for bioremediation and biorestoration tasks.

Temperature is one of the main factors determining the distribution and abundance of species due to its effects on enzymatic activities (Aguilera, Souza-Egipsy, \& Amils, 2012). Therefore, thermophilic algae have thermal tolerant molecules that constitute their cells, while their metabolism is based on thermostable enzymes (Singleton \& Amelunxen, 1973). A good example of a biotechnological use of thermophilic algae is the bioethanol production (Li, Du, \& Liu, 2008) and the obtaining of poly- $\beta$-hydroxybutyrate from Synechococcus spp., a compound used to degrade plastics (Nishioka et al., 2002), among other biorefinery products. Another interesting suggestion comes from Ramachandra, Mahapatra, and Gordon (2009): where thermophilic diatoms that harbor symbiotic nitrogenfixing Cyanoprokaryota for use in solar panels subject to solar heating.

It is well known that thermal ecosystems support microalgal communities dominating total ecosystem biomass and productivity (Aguilera et al., 2012; Hindák, Kvíderová, \& Lukavský, 2013; Jonker, van Ginkel, \& Olivier, 2013; Nikulina \& Kociolek, 2011; Reisser, 2013; Stockner, 1967). Since 1969, Castenholz comments that thermal pollution from the water-coolant of power plants (nuclear and conventional) promoted microalgae growth. Previous reports indicated the presence of thermophilic microalgae in thermoelectric power plants, as those overgrowing on the concrete walls of a cooling tower at 4 different plants in the Czech Republic (Hauer, 2010) or in Belchatów, central Poland (Hindák, Wołowski, \& Hindáková, 2011), as well as in the woody structure of cooling towers of the thermoelectric power plant of Villa de Reyes in San Luis Potosí (Central Mexico), at $48-50^{\circ} \mathrm{C}$ and $\mathrm{pH} 7.5$ (Covarrubias, 2011).

The cooling towers are used to remove the heat from water via their partial vaporization through a heat-exchanger, via convective heat transfer with dry and cold air. Because the towers are exposed to solar radiation, their woody structures are colonized by a vast biomass of thermophilic microalgae. The presence of microalgae is also explained because the cooling systems are supplied with wastewater from the city of San Luis Potosí. The thermoelectric power plant aims to design a cooling pond for heat rejection as an algae bioreactor pond with the algae that inhabit the top of the cooling towers (sensu Leffler, Bradshaw, Groll, \& Garimella, 2012), because (1) these algae are removed periodically in order to prevent clogging of filter systems of the water recycler; (2) the algae may fix $\mathrm{CO}_{2}$ from flue gases, and (3) they seek to use the biomass generated, as biofuel or biofertilizer. Therefore, the objective of this work was to identify the thermophilic microalgae colonizing the top of a cooling tower, a thermal and human-made ambience. We are interested in these conspicuous microorganisms and are removed periodically from the cooling towers, as they may be used in an algae bioreactor pond.

\section{Materials and methods}

Microalgae and water samples were taken in the middle of the Summer (August 2009), in one of the cooling towers (Fig. 1a) of the thermoelectric power plant of Villa de Reyes in Central Mexico $\left(21^{\circ} 48^{\prime} 19^{\prime \prime} \mathrm{N}, 100^{\circ} 56^{\prime} 00^{\prime \prime} \mathrm{W}\right)$. The thermoelectric plant is located in a high-altitude zone of the semiarid Mexican Plateau (1,820 m.a.s.1.).

The sampled microalgae were growing as abundant and dense brown-green mats, loosely attached to the wooden floor (Fig. 1b) on the top of a cooling tower, with quite constant temperature and considerably water turbulence (Fig. 1c). Three samples of microalgae mats were collected with a spatula; the mats were submerged and attached to the wooden structure of the cooling tower. The samples were mixed to obtain one mixed sample, which was finally transferred to 2 glass flasks of $250 \mathrm{~mL}$, previously acid rinsed $\left(24 \mathrm{~h}\right.$ in $\left.15 \% \mathrm{HNO}_{3}\right)$ and sterilized. In the laboratory, a flask with the mixed sample of microalgae was used for microscopic observation, and the second flask was stored at $-70{ }^{\circ} \mathrm{C}$ until use for total DNA extraction. A sample of the water $(500 \mathrm{~mL})$ was also collected per triplicate, in the same site where the microalgae were taken. The water samples were transported to the laboratory in a cooler and kept refrigerated until the chemical analysis. In the sampling site, $\mathrm{pH}$ (pHmeter Orion 3STAR BenchTop), temperature and light intensity (Photometer EXTECH, 401027) were recorded.

The water samples were prepared for their chemical analysis, which includes the concentration of soluble sulfates $\left(\mathrm{SO}_{4}{ }^{2-}\right)$ by turbidimetry, carbonates $\left(\mathrm{CO}_{3}{ }^{2-}\right)$ and bicarbonates $\left(\mathrm{HCO}_{3}{ }^{-}\right)$ by titration, nitrites $\left(\mathrm{NO}_{2}{ }^{-}\right)$and nitrates $\left(\mathrm{NO}_{3}{ }^{-}\right)$by spectrophotometry (Shimadzu, model UV-2501 PC); biochemical 


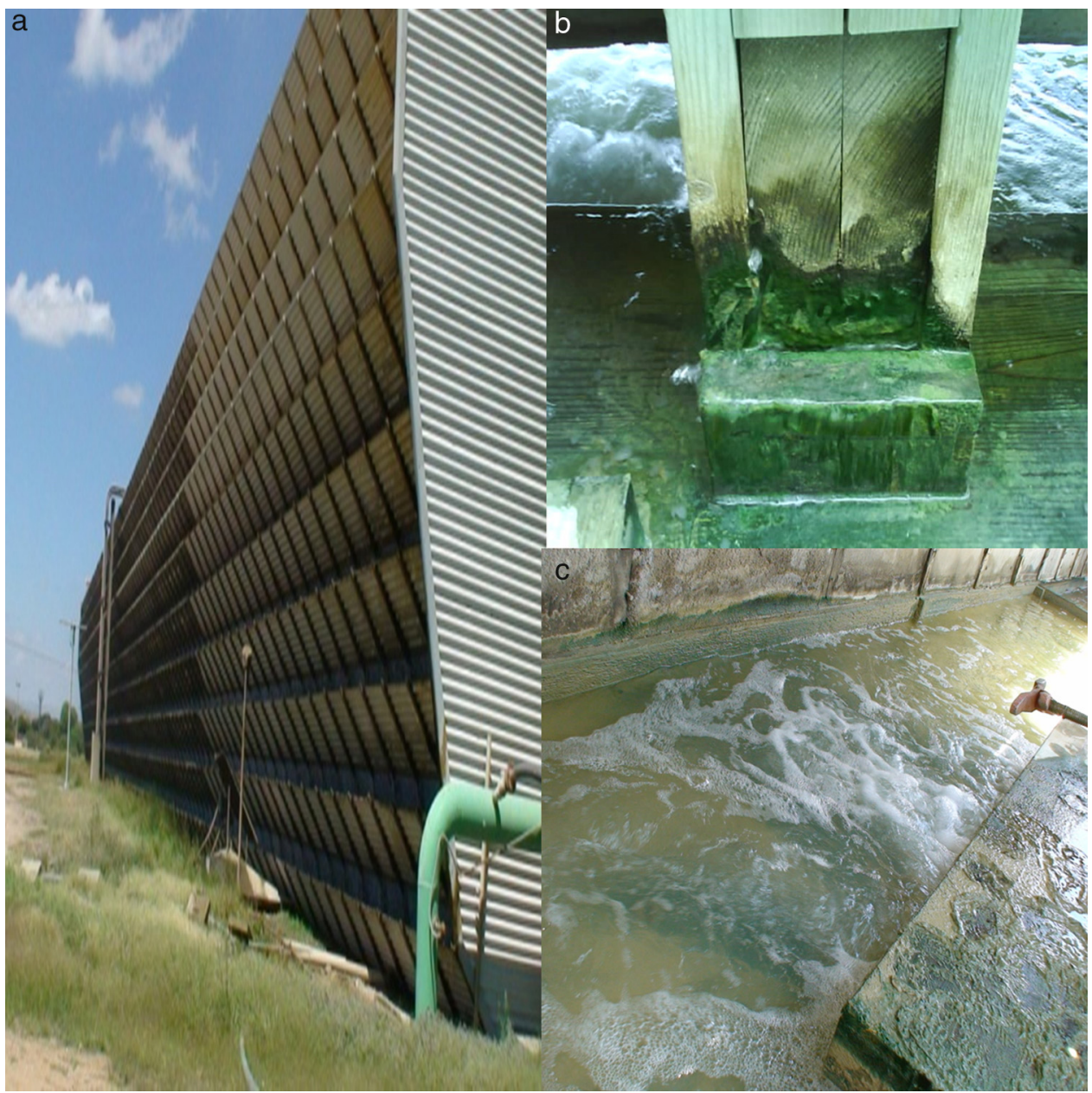

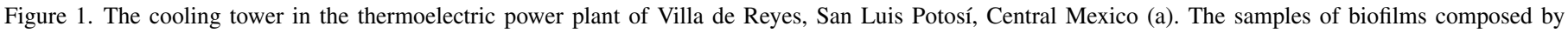
microalgae were taken at the top of the tower (b). Floor of the cancels in the top of the tower with microalgal mats, showing the turbulence of the water (c).

and chemical oxygen demand (BOD and DOQ) were obtained using the Winkler and digestion in close flux methods, respectively. The analyses were done according the Mexican Norm NOM-001-Semarnat (1996). Sodium (Na), calcium (Ca), and potassium $(\mathrm{K})$ were also quantified in the water samples using an atomic absorption spectroscopy (Perkin Elmer 2380). Previously, the water samples were filtered with a $0.45-\mu \mathrm{m}$ pore size membrane (cellulose). All the analyses were done in the Laboratory of Environmental Engineering (Faculty of Chemistry, UASLP), per triplicate.

\section{DNA extraction, PCR amplification and phylogenetic analysis}

The harvested samples were vacuum dried, frozen in liquid nitrogen, and ground to a fine powder using a mortar and pestle under liquid nitrogen. Total DNA extraction from microalgae was performed using harsh lyses method described by Gabor, de Fries, and Janssen (2003) and Casas-Flores, Gómez-Rodríguez, and García-Meza (2015) with minor modification. Samples were centrifuged at 3,000 rpm during $15 \mathrm{~min}$, in order to concentrate the biomass. $150 \mu \mathrm{L}$ of mat sample was suspended in $750 \mu \mathrm{L}$ of lysis buffer (100 mM Tris pH 8.0, $100 \mathrm{mM}$ EDTA pH 8.0,
$1.5 \mathrm{M} \mathrm{NaCl}, 1 \% \mathrm{CTAB}$ ) containing $2.5 \mathrm{mg} / \mathrm{mL}$ of lysozyme, $1 \mathrm{mg} / \mathrm{mL}$ of proteinase $\mathrm{K}$ and $0.7 \mathrm{~g}$ of 0.1 -mm-diameter zirconium beads; afterward, the suspension was incubated at $37^{\circ} \mathrm{C}$ for $8 \mathrm{~min}$. Samples were mixed in a mini-bead beater at top speed for $8 \mathrm{~min}$ in the presence of $200 \mu \mathrm{L} \mathrm{SDS}$ at $20 \%$ (w/v), incubated at $65^{\circ} \mathrm{C}$ for $2 \mathrm{~h}$ mixing every $30 \mathrm{~min}$. The obtained unique sample was centrifuged for $10 \mathrm{~min}$, and the buttons were washed with $500 \mu \mathrm{L}$ of lysis buffer, mixed, incubated at $65^{\circ} \mathrm{C}$ for $10 \mathrm{~min}$ and centrifuged; afterward, 24:1 chloroform: isoamyl alcohol was added, and the mixture was centrifuged for $10 \mathrm{~min}$. Nucleic acids were precipitated from aqueous phase with 0.6 volume of isopropanol and incubated at $4{ }^{\circ} \mathrm{C}$ overnight. The DNA pellet was then washed with $70 \%$ ethanol and suspended in TE buffer $1 \times(\mathrm{pH} 8)$.

Total DNA was preserved at $-20^{\circ} \mathrm{C}$, and this was used as template for PCR amplification of the $16 \mathrm{~S}$ and $18 \mathrm{~S}$ rDNA, using $1 \mu \mathrm{L}$ of total DNA for a final volume of $25 \mu \mathrm{L}$. For $16 \mathrm{~S}$, oligonucleotides 533F ( $5^{\prime}$-GAGTTTGATC/TA/CTGGCTCAG-3 $\left.{ }^{\prime}\right)$ and 1492R (5'-CGGC/TTACCTTGTTACGAC-3') were used to amplify a 950-bp region of the 16S rDNA gene (Bond, Smriga, $\&$ Banfield, 2000). The reaction mixture containing, $1 \times$ PCR buffer, $200 \mu \mathrm{M}$ of dNTPs, $1 \mu \mathrm{M}$ of each forward and reverse primers, and $1.25 \mathrm{U}$ of Taq polymerase (Promega). Negative 
controls with water were included. Touch gene gradient or TC-2720 thermocycler (Applied Biosystems) was used to incubate reactions with an initial denaturizing step at $94{ }^{\circ} \mathrm{C}$ during $2 \mathrm{~min}$, followed by 30 cycles at $94{ }^{\circ} \mathrm{C}$ for $1 \mathrm{~min}, 60^{\circ} \mathrm{C}$ for $1 \mathrm{~min}$ and $72^{\circ} \mathrm{C}$ for $1: 30 \mathrm{~min}$ and completed with an extension at $72^{\circ} \mathrm{C}$ per $7 \mathrm{~min}$. PCR products were resolved on a $1.5 \%$ agarose gel. Amplified PCR product was directly cloned into pGEM-T Easy (Promega) according to the manufacturer's instructions, Escherichia coli Top-10F'cells prepared for transformation and recombinants were selected with Luria-Bertani agar plates, containing $0.1 \mathrm{mg} / \mathrm{mL}$ of carbenicillin, and incubated at $37^{\circ} \mathrm{C}$ for $18 \mathrm{~h}$. Recombinant plasmids were extracted as described by Birnboim and Doly (1979), and recombinant plasmids were purified with Kit Wizard Sv Gel and PCR clean-up system. Finally, amplicons were sequenced according to Sanger, Nicklen, and Coulson (1977).

For the rDNA 18S, we used the universal eukaryote primers $82 \mathrm{~F}\left(5^{\prime}\right.$-GAAACTGCGAATGGCTC-3') Proto/5R (5' GACGGGCGGTGTGTAC-3') (Auinger, Pfandl, \& Boenigk, 2008) amplified in a PCR as shown in fingerprints. Touchgene gradient or TC-2720 thermocycler (Applied Biosystems) was used to incubate reactions with an initial denaturizing step at $94{ }^{\circ} \mathrm{C}$ for $5 \mathrm{~min}$; 35 cycles at $94{ }^{\circ} \mathrm{C}$ for $30 \mathrm{~s}$ (lowering $0.2{ }^{\circ} \mathrm{C}$ each cycle) for $30 \mathrm{~s}$ and $72^{\circ} \mathrm{C}$ for $1 \mathrm{~min}$, and completed with an extension at $72^{\circ} \mathrm{C}$ per $7 \mathrm{~min}$. From here on, the samples were treated as described in 16S rDNA genes.

The phylogenetic relationships were determined by comparing their $16 \mathrm{~S}$ or $18 \mathrm{~S}$ rDNA sequences against those of NCBI (http://blast.ncbi.nlm.nih.gov/) database, using the BLAST program. The 16S rDNA sequences obtained from NCBI were aligned with those obtained in this work using the MEGA5 software (version 5.1) (Tamura, Stecher, Peterson, Filipsk, \& Kumar, 2013) by the neighbor-joining method. Thus, the evolutionary history was inferred by using the maximum likelihood method based on the Saitou-Nei model (Saitou \& Nei, 1987). The tree with the highest log likelihood (0.92306470) is shown. The tree is drawn to scale, with branch lengths in the same units as those of the evolutionary distances used to infer the phylogenetic tree. The evolutionary distances were computed using the Maximum Composite Likelihood method (Tamura, Nei, \& Kumar, 2004)

Table 1

Some characteristics of the identified microalgae sampled in the cooling tower in the thermoelectric power plant of Villa de Reyes.

\begin{tabular}{|c|c|c|c|c|}
\hline No. sequence designated & $\begin{array}{l}\text { Taxonomic } \\
\text { assignment (GenBank } \\
\text { access number) }\end{array}$ & No. of clones & Percent of identity & Features from literature \\
\hline
\end{tabular}

M1.8

$\begin{array}{lll}\text { Arthronema } & 15 & 96 \% \text { with } A . \\ \text { africanum } & \text { africanum } \\ \text { (JX470582) } & & \text { AB115966.1 and } \\ & \text { KM019974.1 }\end{array}$

M1.10 and M1.21

Chroococcidiopsis spp. (JX470581)

6 AJ344554, $C$.
thermalis AB074506.1 among others (Table 3)

M3.7 Chlorogloeopsis fritschii (JX470580.1)

2 fritschii (JX470580.1)

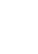

M1.7

Scenedesmus sp. (JX524611)

15 97\% with
Scenedesmus sp.
JX910112.1

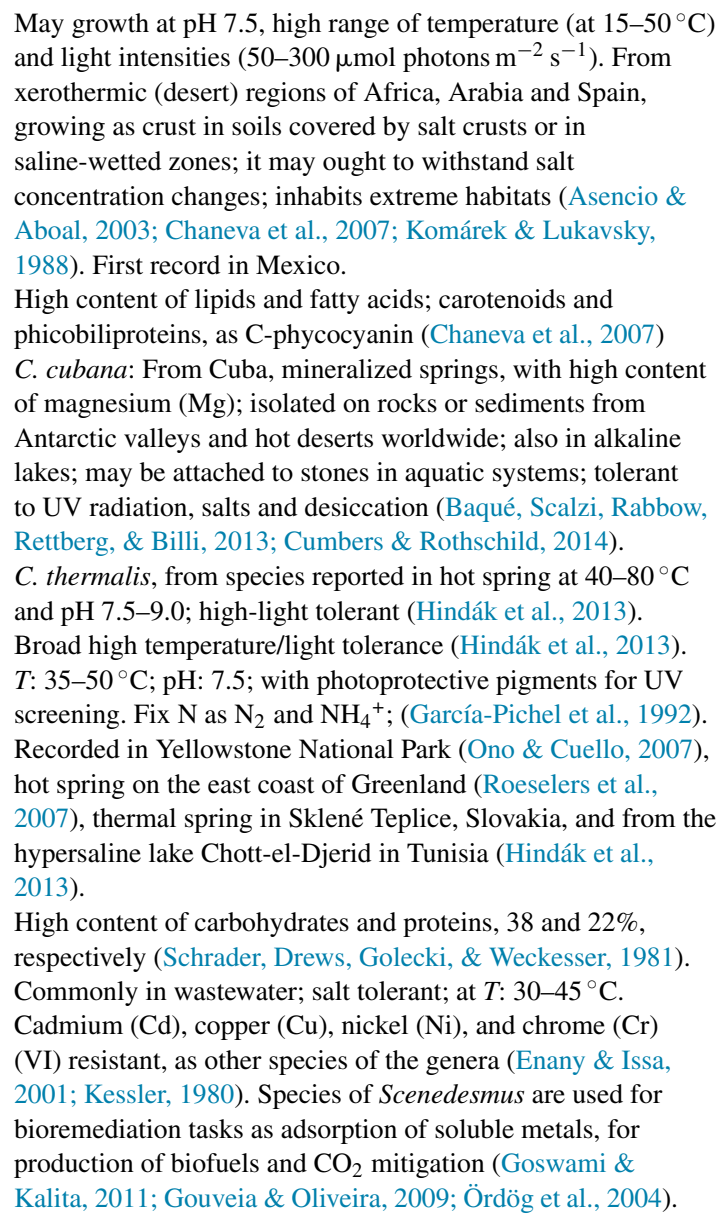


Table 2

Some characteristics of the sampled water collected (per triplicate) in the same site where the microalgae were taken. Data: $n=3$.

\begin{tabular}{ll}
\hline Parameter & Average \pm standard deviation \\
\hline $\mathrm{pH}$ & $7.19+0.16$ \\
& Concentration $\left(\mathrm{mg} \mathrm{L}^{-1}\right)$ \\
Dissolved $\mathrm{O}_{2}$ & $7.98 \pm 0.22$ \\
$\mathrm{BOD}\left(\mathrm{mg} \mathrm{O}_{2} \mathrm{~L}^{-1}\right)$ & $5.06 \pm 0.82$ \\
$\mathrm{COD}\left(\mathrm{mg} \mathrm{O}_{2} \mathrm{~L}^{-1}\right)$ & $76.77 \pm 19.55$ \\
Total hardness $\left(\mathrm{CaCO}_{3}\right)$ & $334.43 \pm 11.95$ \\
Dissolved $\mathrm{SiO}_{2}$ & $92.95 \pm 3.15$ \\
Organic N & $2.53 \pm 0.22$ \\
Nitrate, $\mathrm{NO}_{3}{ }^{-}$ & $56.50 \pm 0.41$ \\
Ammonium, $\mathrm{NH}_{4}{ }^{+}$ & $0.27 \pm 0.14$ \\
Phosphorus, $\mathrm{P}_{\text {total }}$ & $8.30 \pm 0.09$ \\
Phosphates, $\mathrm{PO}_{4}{ }^{2-}$ & $25.55 \pm 9$ \\
Sulfates, $\mathrm{SO}_{4}{ }^{2-}$ & $983.17 \pm 13.93$ \\
Chloride, $\mathrm{Cl}^{+}$ & $252.67 \pm 9.10$ \\
Sodium, $\mathrm{Na}^{+}$ & $211 \pm 0$ \\
Potassium, $\mathrm{K}^{+}$ & $48 \pm 0$ \\
Calcium, $\mathrm{Ca}^{2+}$ & $137.72 \pm 4.92$ \\
Magnesium, $\mathrm{Mg}^{2+}$ & $23.80 \pm 2.42$ \\
\hline
\end{tabular}

BOD: biochemical oxygen demand; DOQ: chemical oxygen demand.

and are in the units of the number of base substitutions per site. The analysis involved 26 nucleotide sequences. Codon positions included were $1 \mathrm{st}+2 \mathrm{nd}+3 \mathrm{rd}+$ Noncoding. All positions containing gaps and missing data were eliminated. There were a total of 786 positions in the final dataset. Evolutionary analyses were conducted in MEGA6 (Tamura et al., 2013).

The obtained sequences of this study were deposited in GenBank and their accession numbers are listed in Table 1.

The sampled microalgae were observed in an optical microscopy Leica (DME) and Olympus (BX51). Observations of the sampled microalgae by light microscopy were done with a microscope Olympus, in order to describe them.

Diatoms, were also analyzed by scanning electron microscopy (SEM, Philips XL30), and specialized literature (Krammer \& Lange-Bertalot, 1986, 1988, 1991), in order to identify them since the described method for DNA extraction was not useful for the cell disruption diatoms due to the silicic nature of the frustule. Diatoms were previously cleansed via thoroughly oxidizing organic material from the wall and cytoplasm using a chromic mixture of nitric acid $\left(\mathrm{HNO}_{3}, 20 \%\right)$ and potassium dichromate $\left(\mathrm{K}_{2} \mathrm{CrO}_{7}\right)$, according to Johansen (in García-Meza, 2009). Cleansed frustules of diatoms were placed in the sample holder and coated with gold (Au) for their observation in the SEM.

\section{Results}

The registered water temperature was $48 \pm 1^{\circ} \mathrm{C}$ at the sampling time (10-12 h), the photic zone attains $11.5 \mathrm{~cm}$ and the light intensity varies with depth between 32.0 and $102.9 \mu \mathrm{mol}$ photons $\mathrm{m}^{-2} \mathrm{~s}^{-1}$ (at 11.5 and $0 \mathrm{~cm}$ depth, respectively).

According to the chemical characteristics of the sampled water (Table 2), the ambience may be suitable to neutrophile ( $\mathrm{pH}$ 6.9-7.3) and oligohalobien (salts $<260 \mathrm{mg} / \mathrm{L}$ ) microalgae, which may use bicarbonates $\left(\mathrm{HCO}_{3}{ }^{-}\right)$and nitrates $\left(\mathrm{NO}_{3}{ }^{2-}\right)$ as carbon $(\mathrm{C})$ and nitrogen $(\mathrm{N})$ sources, respectively. The ionic dominance was $\mathrm{SO}_{4}{ }^{2-}>\mathrm{CO}_{3}{ }^{2-}>\mathrm{Cl}^{+}>\mathrm{Ca}^{2+}>\mathrm{Na}^{+}>\mathrm{HCO}_{3}-$ $>\mathrm{NO}_{3}-\mathrm{K}^{+} \gg \mathrm{PO}_{4}{ }^{2-}>\mathrm{Mg}^{2+}$.

The highly available carbonate reacts with the $\mathrm{CO}_{2}$ from the power plant, resulting in a high bicarbonate concentration (Table 2); this buffering reaction maintains the $\mathrm{pH}$ of the water.

It is important to say that the water is reused 3 times in the cooling-cycle; afterwards, the water is thrown out because it increases the concentration of contained salts; the water taken during the sampling days corresponds to the first cycle, with the lowest salt and organic matter concentration, but with high concentrations of $\mathrm{CaCO}_{3}$ (>438 mg/L) (Table 2).

Based on their morphological description (Table 4) and their 16S rRNA sequences, the microalgae include 3 genera of Cyanoprokaryota (Fig. 2; Table 1): non-heterocytes $\mathrm{N}_{2}$ fixing Chroococcidiopsis (Pleurocapsal), a non-heterocytous filamentous Arthronema (Oscillatorial), 96\% identical to A. africanum (Schwabe \& Simonsen) Komárek \& Lukavsky (NCBI AB115966.1 and KM019974.1), and a heterocytous Chlorogloeopsis (Nostocal), 99\% identity with C. fritschii (A.K. Mitra) A.K. Mitra \& D.C. Pandey (NCBI AF132777.1, AB093489.1, and AB075981.1). However, 6 cloned sequences of Chroococcidiopsis sp. JX470581 produced significant alignments and showed 99\% identity with the 16S RNA genes of clones designated M1.10 and M1.21 in this work (Table 3).

Eukaryotic microalgae are represented by 2 chlorophytes Scenedesmus spp. JX524611, and Scenedesmus armatus KC505541 (R. Chodat) R. Chodat (Tables 1 and 4) and 12 species of diatoms (Fig. 3, Table 4).

The identified diatoms are Nitzschia hantzchiana Rabenhorst, N. microcephala Grunow, N. sp., Pinnularia latarea var. thermophile K. Krammer, Luticula goeppertiana (Bleisch) Mann, Gomphonema parvulum (Kützing) Kützing, Achnanthidium exiguum (Grunow) D. B. Czarnecki, Amphora ovalis (Kützing) Kützing, A. veneta Kützing, and A. pediculus (Kützing) Grunow ex A. Schmidt (Order Pennales), as well as Stephanocyclus menenghiniana (Kützing) Skabitschevsky and Stephanodiscus sp. (Order Centrales).

\section{Discussion}

This work represents the first report of a thermophilic community of microalgae from a power plant in Mexico. It is an extreme human-made ambience, whose principal characteristic is the high temperature of the water used in the cooling tower $\left(48-50{ }^{\circ} \mathrm{C}\right)$. In extreme environments, phototrophic microorganisms are frequently found forming thick microbial mats (Aguilera et al., 2012; Tuchman \& Blinn, 1979). Also, at the top of the studied cooling tower, the microalgae were growing as conspicuous and dense brown-green mats (Fig. 1b), mainly composed by filamentous microalgae of about $1.5-2 \mathrm{~cm}$ width; such mats covered ca. $70 \%$ of the wooden floor, to which these were strongly adhered due to the continued water flux, (Fig. 1c). However, the sampling was done during the first cycle when the extent and thickness of mats was the lowest: the extent of microalgal mats changes according to water management changes, 


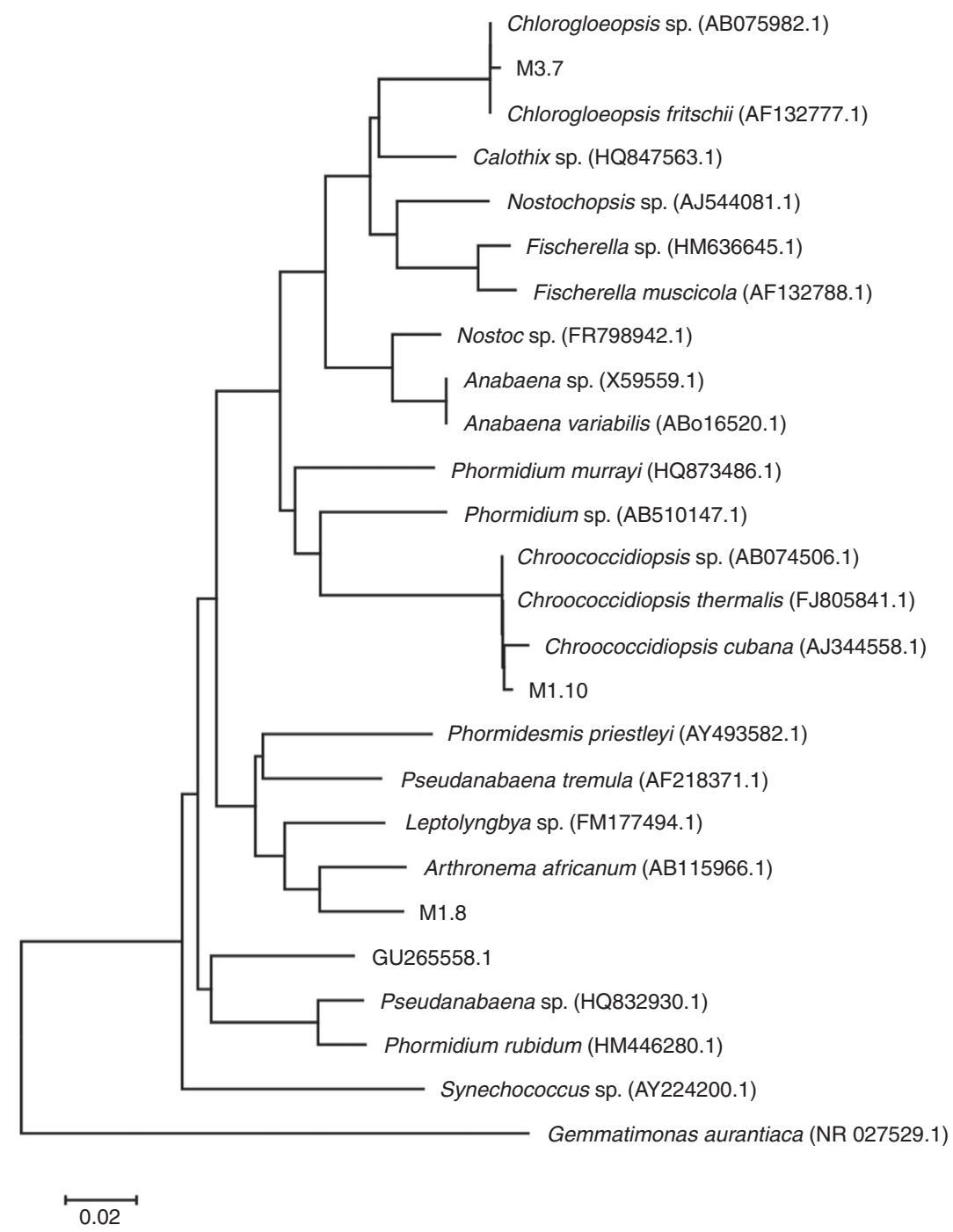

Figure 2. Phylogenetic tree showing relationship of the sequences found in our samples to representative Cyanoprokaryota16S rDNA genes. Sequences of the cyanobacteria were retrieved from GenBank. The evolutionary history was inferred using the neighbor-joining method. The optimal tree with the sum of branch length $=0.92306470$ is shown. Out group: Gemmatimonas aurantiaca .

since this management alters the amount and proportion of nutrients; e.g. the water comprises 50 and $300 \mathrm{mg} \mathrm{L}^{-1}$ of $\mathrm{SiO}_{2}$ and 11 and $35 \mathrm{mg} \mathrm{L}^{-1}$ of phosphates in the first and third cycle, respectively.
Despite the conspicuousness of microalgal mats, the microscopically observed mats showed low species richness compared with other reports of thermal regions, as well as previous research on cooling towers in the Czech Republic, and in central

Table 3

Sequences of Chroococcidiopsis sp. JX470581 producing significant alignments with gene for 16S ribosomal RNA designated M1.10 and M1.21 (from www.ncbi.nlm.nih.gov/genbank).

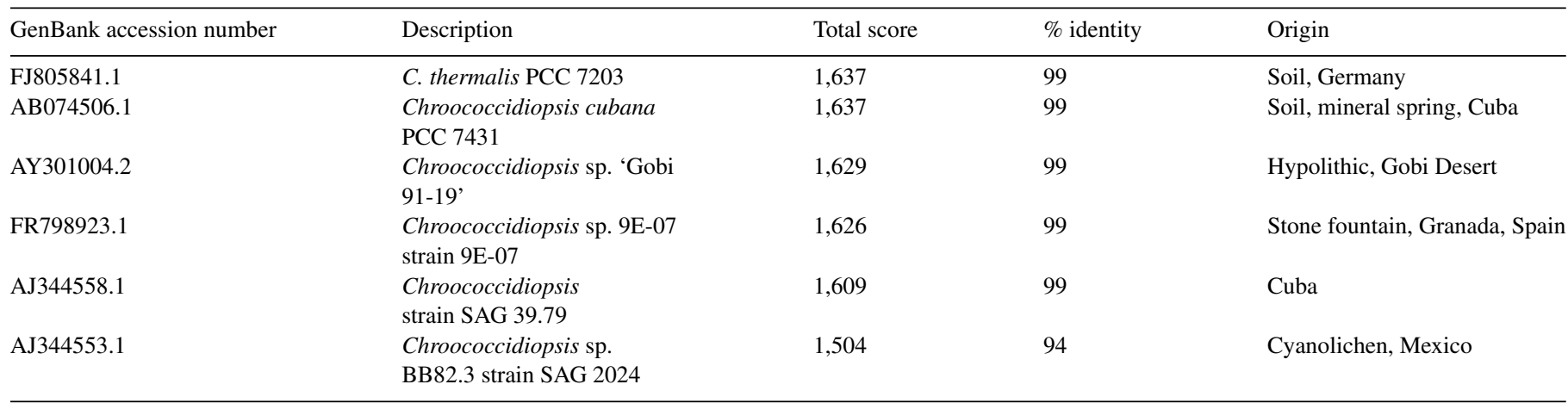


Poland, wherein the algae grow on the concrete walls, as a result of sprayed water (Hauer, 2010; Hindák et al., 2011); although the algal growth in the cooling tower may be primarily due to the $\mathrm{CO}_{2}$ emanated by the power plant, as was suggested by Edwards (2008) and Douskova et al. (2009). The low species richness may be explained as consequence of the changeability of this human-made ambience; e.g. water turbulence amends constantly the quality and quantity of light; in contrast, most thermal pools are clear and usually shallow, and show low radiation extinction and have remarkably constant chemical composition and temperature (Castenholz, 1969).

The identified microalgae include 3 species of Cyanoprokaryota, previously reported as thermophilic (Chaneva, Furnadzhieva, Minkova, \& Lukavsky, 2007; Hindák et al.,
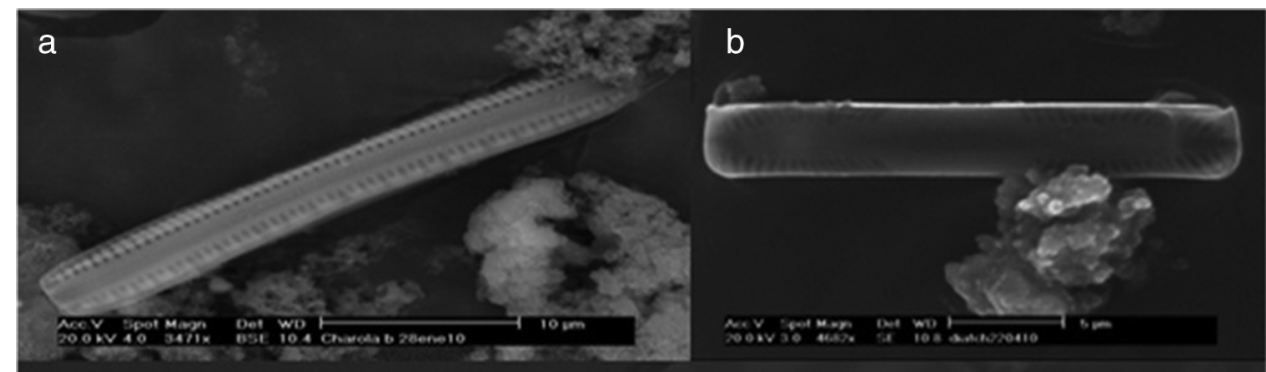

c

d
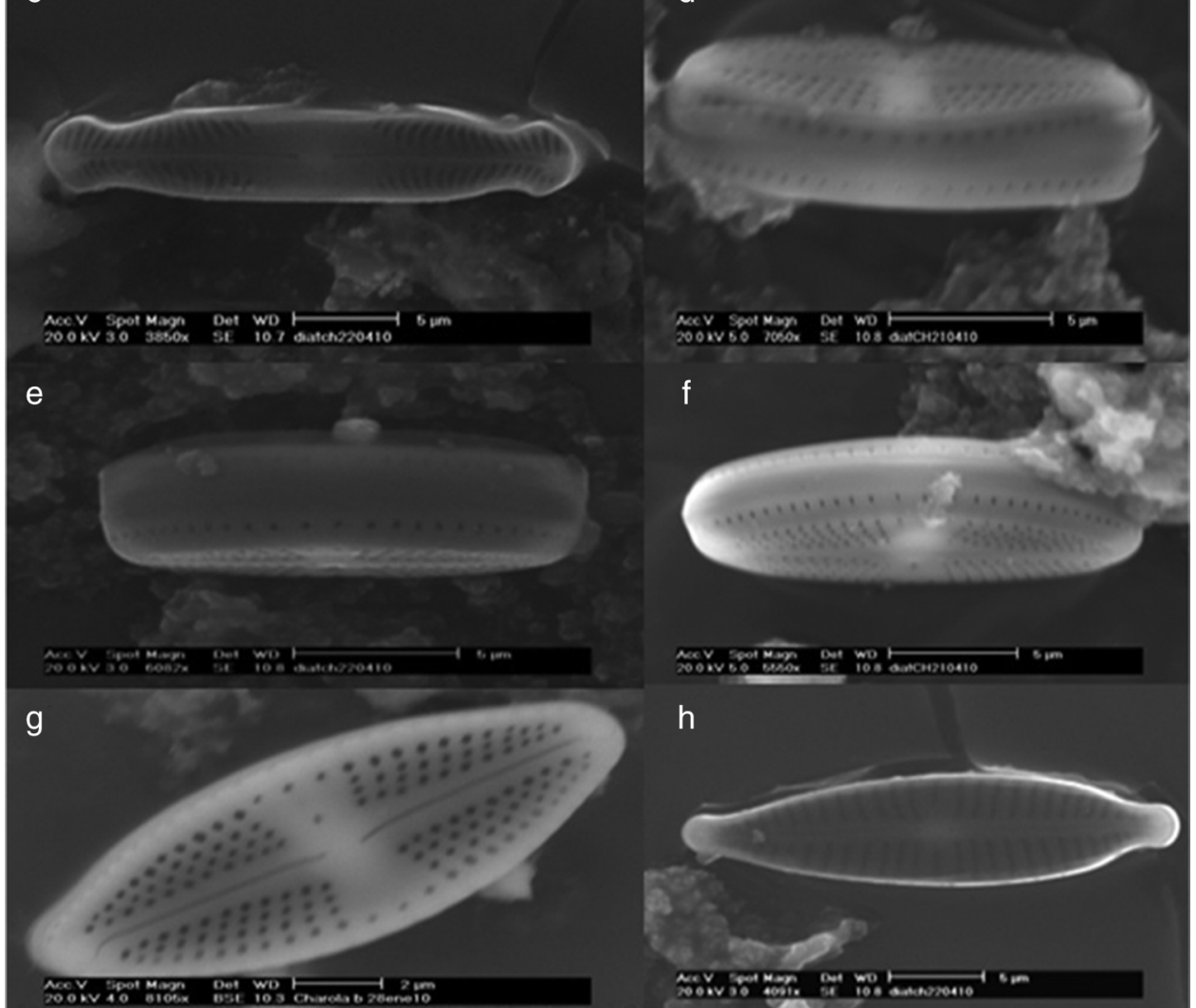

$\mathrm{h}$

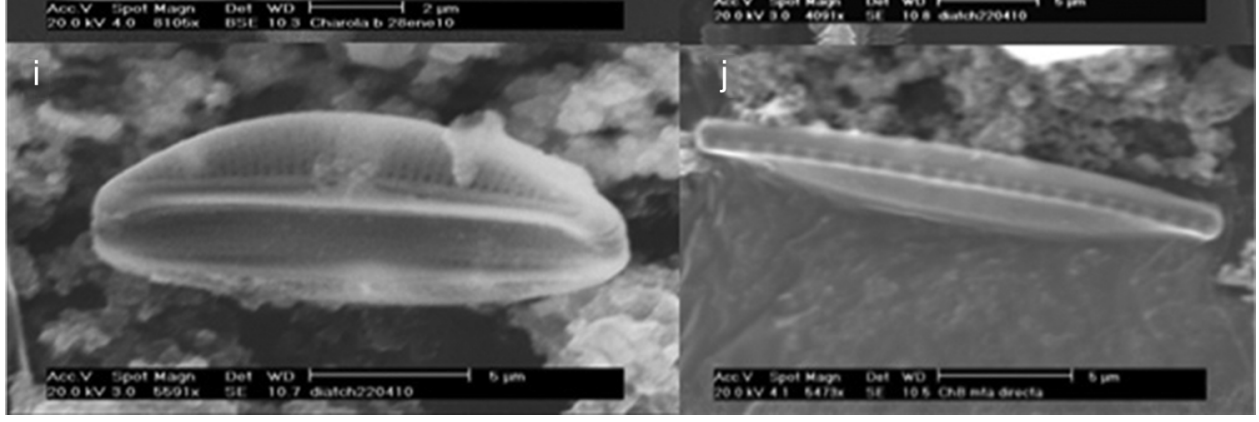

Figure 3. Thermophilic diatoms observed at SEM. Nitzschia sp., cingulum (a); Pinnularia latarea var. thermophila (b and c); Luticula goeppertiana, cingulum (d, e, and f) and valvar view (g); Gomphonema parvulum (h); Amphora ovalis (i); Nitzschia hantzchiana, cingulum (j) and valvar view (k); Nitzschia microcephala (1);

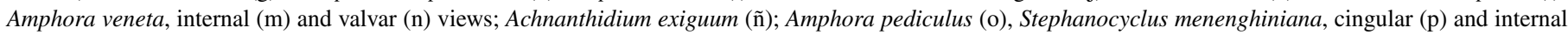
(q) views; Stephanodiscus sp. (r). 


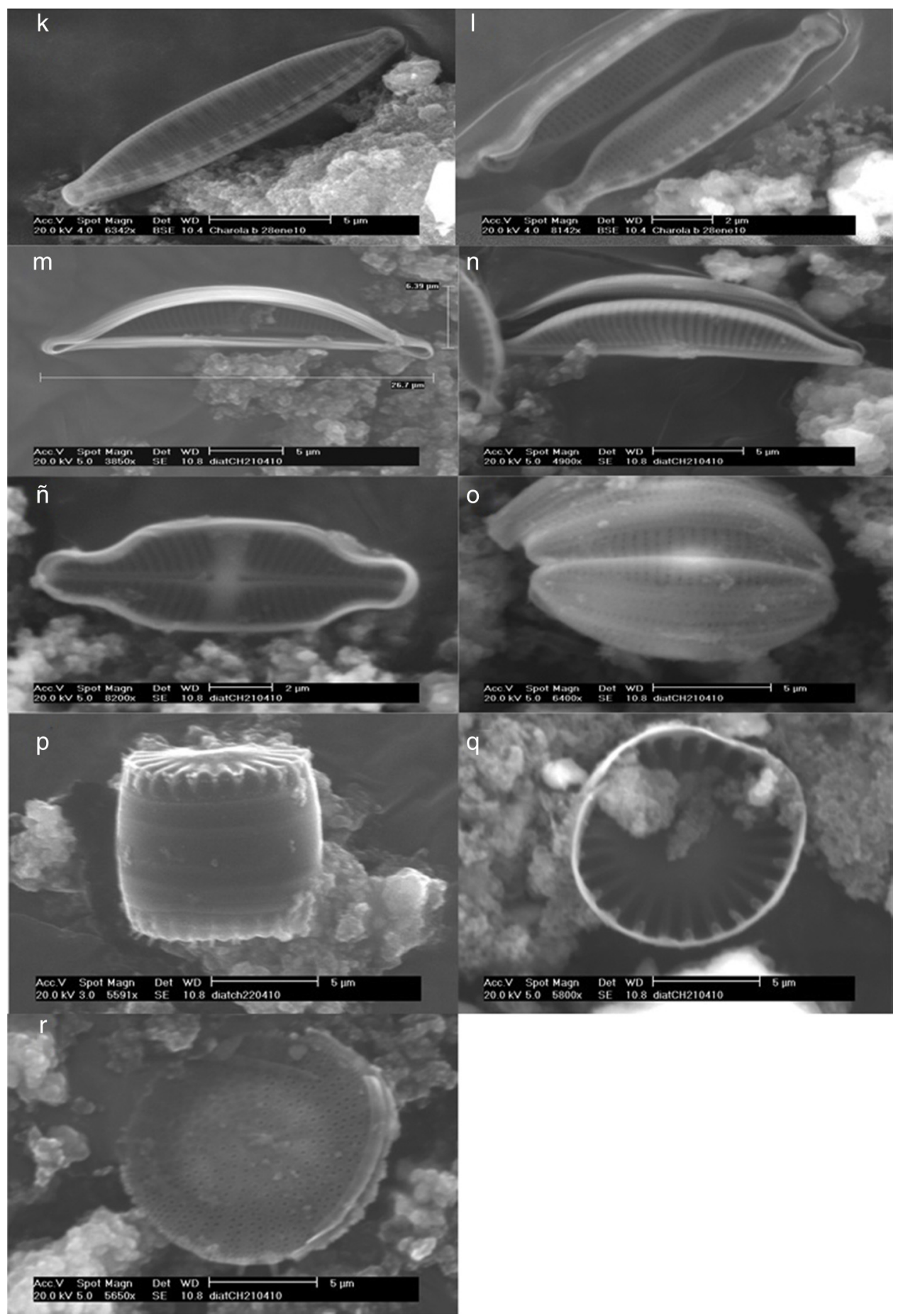

Fig. 3. (Continued)

2013). Arthronema africanum JX470582 was the most common Cyanoprokaryota in the sampled mats (microscopic observation). A. africanum may grow under a wide range of temperatures and light intensities (Table 1) due to its protective mechanism against high irradiation intensity, e.g. contents of phycobiliproteins and carotenoids increase with temperature and light intensity (Asencio \& Aboal, 2003). Furthermore, A. africanum has a pantropical distribution (Hoffmann, 1996).
Species of the genus Chlorogloeopsis have been identified as thermophiles, with broad tolerance to light intensity (Hindák et al., 2013), also due to photoprotective pigments (GarcíaPichel, Sherry, \& Castenholz, 1992; Ono \& Cuello, 2007). For this genus, our phylogenetic analysis of 16S rRNA gene sequences affiliated with Chlorogloeopsis fritschii AF132777.1 and AB093489.1 (95\% identity); the latter has already been described in thermal environments such as in hot springs of Greenland, at $49^{\circ} \mathrm{C}$, for the first time by Roeselers et al. (2007). 
Table 4

Morphological descriptions of the identified microalgae from the cooling tower in the thermoelectric power plant of Villa de Reyes.

Microorganisms
Arthronema africanum JX470582
Chroococcidiopsis spp. JX470581
Chlorogloeopsis fritschii JX470580.1

Scenedesmus spp. JX524611

Scenedesmus armatus KC505541

Nitzschia hantzchiana

N. microcephala

Pinnularia latarea var. thermophile

Luticula goeppertiana

Gomphonema parvulum

Achnanthidium exiguum

Amphora ovalis

A. veneta

A. pediculus

Stephanocyclus menenghiniana

Stephanodiscus sp.

\section{Description}

Simple, blue-green, unbranched, slightly waved, narrow, and unconstrained filaments, forming diffluent mats, without mucilage or sheath. Cells of the same size, longer than wide, ca. $1 \mathrm{~mm}$ wide; polar cells slightly cylindrical and rounded end. Non-motile thricome. Reproduction by trichome fragmentation. Unicellular, more or less spherical and blue-green to yellowish cells, living in more or less spherical colonies surrounded by a thin sheath. 2-4 $\mu \mathrm{m}$ diameter. Successive cell division (binary), 4-8 daughter cells within enveloping sheath.

Aggregated cells or simple, pale blue-green, uniseriated, and short pseudofilament, within a thin sheath. Cylindrical cells of different size, sometimes slightly spherical, longer than wide; terminal to subterminal heterocyte in small thricomes. Form hormogonia of smaller cylindrical cells.

Cenobium of 4 cells linearly arranged; elliptical, cylindrical and spineless cells; identical cells, joined laterally (attached side by side), overlapping; round poles; a single and centric pyrenoid.

Cenobium of 4 cells attached side by side, and linearly arranged; elliptical cells, terminal cells with 1 spine in each end; a single centric to subcentric pyrenoid.

Lineal-lanceolate valves; straight in valvar view; straight to slightly convex margins; poles are cuneate or rounded; straight apical axis; transversal stria are dotted and straight; short fibulae, equidistant between them. Length: 12-24 $\mu \mathrm{m}$; width: 3-3.5 $\mu \mathrm{m}$.

Isopolar frustule; symmetric; poles are capitate-rounded; straight apical axis; straight apical axis; transversal stria are dotted; short and flat fibulae, equidistant between them. Length: $7-8 \mu \mathrm{m}$; width: 2-3 $\mu \mathrm{m}$.

Lineal-lanceolate and symmetric valves; straight to undulated margins; isopolar frustule; subcapitate-rounded poles; central area is cross for stauros shape; single raphe, filiform with distal ends curved; radial striae at the poles. Length: $20-25 \mu \mathrm{m}$; width: $2-4 \mu \mathrm{m}$.

Elliptic-lanceolate valve; convex margins; poles are not differentiated; rounded apices; raphe slightly lanceolate with proximal ends curved; straight axial area; central area is stauros-shape, with a round stigma; radial striae, and conspicuously dotted. A central pore. Length: $14 \mu \mathrm{m}$; width: $7 \mu \mathrm{m}$.

Valves slightly asymmetric with respect the trans-apical axis (heteropolar) but symmetric referred to apical axis; subcapitate rounded apices; sinuous raphe; thick striae; a short stria in central area; the striae become radials toward the center. Length: $25 \mu \mathrm{m}$; width: $5 \mu \mathrm{m}$.

Valves are elliptic to elliptic-lanceolate; capitate to subrostrate apices; the raphe presents stauro often is slightly wider on one side; the distal ends of the raphe are curved in opposite direction. Denser striae in the valve with raphe; striae display a radial arrangement in both valves, but become slightly parallels toward the apices. Length: $15 \mu \mathrm{m}$; width: $3 \mu \mathrm{m}$.

Arched valves, lanceolate, dorsi-ventral (valvar view); biconvex cells with dorsal margin more prominent than the ventral margin; lateral raphe; with proximal and distal ends slightly curved toward the dorsal margin. Parallel striae at the central area and become slightly radials toward the apices; rounded apices. Length: $16 \mu \mathrm{m}$; width: $5 \mu \mathrm{m}$.

Elliptic cells (valvar view); protuberant apices, rounded and straight or ventrally curved. Both margins, ventral and dorsal, are convex or slightly convex; a narrow and straight axial area; axial area is lanceolate or is arched dorsally. Lateral raphe; raphe is interrupted at central area; the proximal ends of raphe are rounded, and the distal ends of the raphe are slightly curved toward the dorsal margin. Parallels striae that become slightly radials toward the apices. Length: $27-45 \mu \mathrm{m}$; width: $10-15 \mu \mathrm{m}$.

Small valves (13-21 $\mu \mathrm{m}$ large); biconvex cells with rounded apices; raphe with proximal and distal ends slightly curved toward the dorsal margin. Parallels striae that become slightly radials toward the apices. Length: 13-21 $\mu \mathrm{m}$; width: 4-6 $\mu \mathrm{m}$.

Cells are drum-shaped. Circular valves with a tangential undulation at the center; well defined marginal zone, and it is clearly distinct from the central area of the valvar surface. Length: $9 \mu \mathrm{m}$ (valvar zone); width: $8 \mu \mathrm{m}$.

Cells are disc, drum or barrel-shaped; single cells or in chains; the valvar surface is flat or undulating concentrically. Radial striae and ordered in packages or "fascicles"; fascicles are separated between them by ribs. Spines are present in the valvar margin; a fultoportula or central tubular process is below of each spine. Length: $10-11 \mu \mathrm{m}$ (valvar zone).
The third Cyanoprokaryota identified was Chroococcidiopsis spp. JX470581. Some Chroococcidiopsis can survive under extreme temperatures (as C. thermalis in thermal springs), high levels of radiation, and high concentrations of salt, (like C. cubana, from mineralized springs). The clones designated M1.10 and M1.21 in this work produced significant alignments and showed $99 \%$ identity with the 16S RNA genes of 5 sequences of Chroococcidiopsis from different geographical origin and life-strategy: C. thermalis PCC 7203 (soil, Germany). C. cubana
PCC 7431 (soil, Cuba), C. sp. 'Gobi 91-19’ (hypolithic, Gobi Desert), C. sp. 9E-07 (on stone fountain, Spain) (Table 3). Moreover, it showed $95 \%$ identity with a Chroococcidiopsis, C. sp. BB82.3 strain SAG 2024 (cyanolichen) from Mexico. The latter suggests that strains from very different geographical regions and habitat types are closely related, especially those from soil and aquatic-living strains from lichenized and rock associations (Donner, 2013). Furthermore, C. cubana and C. thermalis are highly similar based on highly conserved genes 
as $16 \mathrm{~S}$ rDNA; however, both species showed differences in their ecology (Table 1; Donner, 2013).

A few and early reports of thermophilic strains of Scenedesmus were presented by Trukhin (1963) and Kessler (1980), while few diatoms are considered thermophilic, tolerating temperatures above $40^{\circ} \mathrm{C}$ (Stockner, 1967), and most of them are benthic, as the 232 species, varieties, and forms of diatoms from 10 hot springs and reservoirs of Sakhalin and Kuril Islands, where temperatures may reach ca. $70{ }^{\circ} \mathrm{C}$ (Nikulina and Kociolek, 2011). In the cited work, the main represented genera are Pinnularia and Nitzschia, as in the thermo-mineral waters of Katlanovska Banja (Stavreva-Veselinovska \& Todorovska, 2010) and Sao Miguel Island, Azores (Quintela et al., 2013). Meanwhile in our work, Nitzschia is the best represented while Pinnularia latarea var. thermophila and Nitzschia hantzschiana are the most common. Among the identified diatoms in this work, Achnanthidium exiguum, Gomphonema parvulum, Amphora ovalis, A. veneta and A. pediculus, have been previously reported as thermophiles, at $40-58^{\circ} \mathrm{C}$ (Mannino, 2007; Nikulina \& Kociolek, 2011; Quintela et al., 2013; StavrevaVeselinovska \& Todorovska, 2010). Unlike the aforementioned studies, in the current study the diatoms were only microscopically observed within the algal mats. It is well known that diatoms acclimate better to low temperature and lower light intensity than Cyanoprokaryotas and Chlorophytes. Thus, the presence of diatoms in our sample may be also due to mucilage-producing Cyanoprokaryota, e.g. Chroococcidiopsis spp.; i.e., the surrounding mucilaginous matrix represents a suitable microenvironment for diatoms. Some species avoid high light intensity and UV light by living within soil or caves, as photobionts in lich symbiosis or within biological soil crust or dense mats or biofilms (Donner, 2013).

The scientific interest in thermophilic microalgae responds to the following facts: (1) there are considerable amount of taxa not yet described that may thrive up to $50^{\circ} \mathrm{C}$; (2) they could very well represent ancient forms related to the origin and evolution of the oxygenic photosynthesis and nitrogen $\left(\mathrm{N}_{2}\right)$ fixing capabilities of Cyanoprokaryota, and (3) they have potential uses as biomaterials or in diverse biotechnologies at high temperatures (Castenholz, 1969). A myriad of applications of the identified algae has been launched (Table 1), such as the power plant that aimed to use the biomass generated as biofuel or biofertilizer. Specifically, Scenedesmus quadricauda and the thermophile Chlorogloeopsis spp. have been suggested by Ono and Cuello (2007) and Goswami and Kalita (2011), respectively, for use in a $\mathrm{CO}_{2}$-mitigating photobioreactor, as is desired by the thermoelectric power plant of Villa de Reyes.

This work expands our knowledge about the environments that may be inhabited or colonized by the microalgae, as thermal $\left(48^{\circ} \mathrm{C}\right)$ and human-made ambience. The achievement of significant biomass of microalgae deeply depends on the availability and intensity of sunlight, water, $\mathrm{CO}_{2}$, and nutrients. All these elements occur in great extent in the cooling towers of the thermoelectric power plant. The screening for species of microalgae must continue to prospect the uses to regional needs, especially now, in a time when we face a crisis of energetic, food and environmental issues. Specifically, we suggest the use of the microalgae that grow naturally in the cooling towers, as inoculum for the algae pond that the thermoelectric power plant devised in order to obtain biofuels or biofertilizer.

To the best of our knowledge, this is the first report about thermophilic communities of microalgae from a Mexican power plant. In addition, this is the first report of A. africanum in Mexico. This study opens new lines of research such as potential application; e.g. A. africanum cultivation to produce phycobiliproteins as colorants.

\section{Acknowledgments}

This work was supported by a Conacyt scholarship number 217539. Financial support for this work comes from the Laboratory of Geomicrobiology, UASLP, and from the División de Biología Molecular, IPICyT. The authors also thank to QFB Alma de Lira Santillán and Dr. Roberto Leyva Ramos of the Laboratory of Environmental Engineering (Faculty of Chemistry, UASLP), for the chemical analysis of the sampled water. This work was possible thanks to the thermoelectric power plant of Villa de Reyes; special thanks to Eng. Sergio Castillo-Zaragoza. Finally, the authors also thank the anonymous reviewers that improved the manuscript.

\section{References}

Aguilera, A., Souza-Egipsy, V., \& Amils, R. (2012). Photosynthesis in extreme environments. Rijeka: Artificial Photosynthesis InTech Europe.

Asencio, A. D., \& Aboal, M. (2003). The presence of Arthronema africanum (Cyanophyceae/Cyanobacteria, Oscillatoriales) in Almeria desert, SE Spain with implications on its biogeographical distribution. Algological Studies, 146, 7-14.

Auinger, B. M., Pfandl, K., \& Boenigk, J. (2008). Improved methodology for identification of protists and microalgae from plankton samples preserved in Lugol's iodine solution: combining microscopic analysis with single-cell PCR. Applied Environmental Microbiology, 74, 2505-2510.

Baqué, M., Scalzi, G., Rabbow, E., Rettberg, P., \& Billi, D. (2013). Biofilm and planktonic lifestyles differently support the resistance of the desert cyanobacterium Chroococcidiopsis under space and martian simulations. Origins of Life and Evolution of Biospheres, 43, 377-389.

Birnboim, H. C., \& Doly, J. (1979). A rapid alkaline extraction procedure for screening recombinant plasmid DNA. Nucleic Acids Research, 7, 1513-1523.

Bond, P., Smriga, S., \& Banfield, J. (2000). Phylogeny of microorganisms populating a thick, subaerial, predominantly lithotrophic biofilm at an extreme acid mine drainage site. Applied Environmental Microbiology, 66, 3842-3849.

Casas-Flores, S., Gómez-Rodríguez, Y. E., \& García-Meza, J. V. (2015). Community of thermoacidophilic and arsenic resistant microorganisms from a deep profile of mine heaps. Applied Microbiology Biotechnology Express, 5 http://dx.doi.org/10.1186/s13568-015-0132-5

Castenholz, R. W. (1969). Thermophilic blue-green algae and the thermal environment. Bacteriological Reviews, 33, 476-504.

Connolly, J., Cadotte, M. W., Brophy, C., Dooley, A., Finn, J., Kirwan, L., et al. (2011). Phylogenetically diverse grasslands are associated with pair wise interspecific processes that increase biomass. Ecology, 92, 1385-1392.

Covarrubias, Y.(2011). Bioabsorción de sílice por diatomeas para el tratamiento de aguas industriales M.Sc. thesis. San Luis Potosí, México: Facultad de Ingeniería, Universidad Autónoma de San Luis Potosí.

Cumbers, J., \& Rothschild, L. J. (2014). Salt tolerance and polyphyly in the cyanobacterium Chroococcidiopsis (Pleurocapsales). Journal of Phycology, 50, 472-482. 
Chaneva, G., Furnadzhieva, S., Minkova, K., \& Lukavsky, J. (2007). Effect of light and temperature on the cyanobacterium Arthronema africanum a prospective phycobiliprotein-producing strain. Journal of Applied Phycology, 19, 537-544.

Donner, A. (2013). The case of Chroococcidiopsis: new phylogenetic and morphological insights into ecological important Cyanobacteria Bachelor thesis. Kaiserslautern, Alemania: Technische Universität Kaiserslautern.

Douskova, I., Doucha, J., Livansky, K., Machat, J., Novak, P., Umysova, D., et al. (2009). Simultaneous flue gas bioremediation and reduction of microalgal biomass production costs. Applied Microbiology and Biotechnology, 82, 79-185.

Edwards, M. R. (2008). Green algae strategy: end oil imports and engineer sustainable food and fuel. Tempe, AZ, USA: Green Independence.

Enany, A. E., \& Issa, A. A. (2001). Proline alleviates heavy metal stress in Scenedesmus armatus. Folia Microbiologica, 46, 227-230.

Gabor, E. M., de Fries, E. J., \& Janssen, D. B. (2003). Efficient recovery of environmental DNA for expression cloning by indirect extraction methods. FEMS Microbiology Ecology, 44, 153-163.

García-Meza, J. V. (2009). Algas en desechos mineros de Guanajuato M.Sc. thesis. México, D.F., Mexico: Facultad de Ciencias, Universidad Nacional Autónoma de México.

García-Pichel, F., Sherry, N. D., \& Castenholz, R. W. (1992). Evidence for an ultraviolet sunscreen role of the extracellular pigment scytonemin in the terrestrial cyanobacterium Chlorogloeopsis sp. Photochemistry and Photobiology, 56, 17-23.

Goswami, R. C. D., \& Kalita, M. C. (2011). Scenedesmus dimorphus and Scenedesmus quadricauda: two potent indigenous microalgae strains for biomass production and $\mathrm{CO}_{2}$ mitigation - a study on their growth behavior and lipid productivity under different concentration of urea as nitrogen source. Journal of Algal Biomass Utilization, 2, 42-49.

Gouveia, L., \& Oliveira, A. C. (2009). Microalgae as a raw material for biofuels production. Journal of Industrial Microbiology and Biotechnology, 36, 269-274.

Hauer, T. (2010). Phototrophic biofilms on the interior walls of the concrete Iterson-type cooling towers. Journal of Applied Phycology, 22, 733-736.

Hindák, F., Kvíderová, J., \& Lukavský, J. (2013). Growth characteristics of selected thermophilic strains of cyanobacteria using crossed gradients of temperature and light. Biologia, 68, 830-837.

Hindák, F., Wołowski, K., \& Hindáková, A. (2011). The epilithon of a cooling tower of the power plant at Belchatów, Poland. Ocean Hydrobiological Studies, 40, 38-43.

Hoffmann, L. (1996). Geographic distribution of freshwater blue-green algae. Biogeography of freshwater algae. Hydrobiologia, 336, 33-40.

Jonker, C. Z., van Ginkel, C., \& Olivier, J. (2013). Association between physical and geochemical characteristics of thermal springs and algal diversity in Limpopo Province, South Africa. Water SA, 39, 95-104.

Kessler, E. (1980). Physiological and biochemical contributions to the taxonomy of the genera Ankistrodesmus and Scenedesmus. Archives Microbiology, 113, $143-144$.

Komárek, J., \& Lukavsky, J. (1988). Arthronema, a new cyanophyte genus from Afro-Asian deserts. Archiv für Hydrobiologie, Supplement, 80, 249-267.

Krammer, K., \& Lange-Bertalot, H. (1986). 2/1, Bacillariophyceae. 1. Teil: Naviculaceae. In H. Ettl, J. Gerloff, H. Heynig, \& D. Mollenhauer (Eds.), Sübwasserflora von Mitteleuropa (pp. 1-876). Stuttgart: Fischer Verlag.

Krammer, K., \& Lange-Bertalot, H. (1988). 2/2. Bacillariophyceae. 2. Teil: Bacillariaceae, Epithemiaceae, Surirellaceae. In H. Ettl, J. Gerloff, H. Heynig, \& D. Mollenhauer (Eds.), Sübwasserflora von Mitteleuropa (pp. 1-596). Stuttgart: Fischer Verlag.

Krammer, K., \& Lange-Bertalot, H. (1991). 2/3. Bacillariophyceae. 3. Teil: Centrales, Fragilariaceae, Eunotiaceae. In H. Ettl, J. Gerloff, H. Heynig, \& D. Mollenhauer (Eds.), Sübwasserflora von Mitteleuropa (pp. 1-596). Stuttgart: Fischer Verlag.
Leffler, R. A., Bradshaw, C. R., Groll, E. A., \& Garimella, S. V. (2012). Alternative heat rejection methods for power plants. Applied Energy, 92, $17-25$.

Li, Q., Du, W., \& Liu, D. (2008). Perspectives or microbial oils for biodiesel production. Applied Microbiology and Biotechnology, 80, 749-756.

Mannino, A. M. (2007). Diatoms from thermal-sulphur waters of Fiume Caldo (North-western Sicily). Cryptogamie Algologie, 28, 385-396.

Nikulina, T. V., \& Kociolek, J. P. (2011). Diatoms from hot springs from Kuril and Sakhalin Islands (Far East, Russia). In J. Seckbach, \& J. P. Kociolek (Eds.), The diatom world (pp. 333-363). Amsterdam: Springer.

Nishioka, M., Nishiuma, H., Miyake, M., Asada, Y., Shimizu, K., \& Taya, M. (2002). Metabolic flux analysis of a poly- $\beta$-hydroxybutyrate producing cyanobacterium, Synechococcus sp. MA19, grow under photoautotrophic conditions. Biotechnology and Bioprocess Engineering, 7, 295-302.

Ono, E., \& Cuello, J. L. (2007). Carbon dioxide mitigation using thermophilic cyanobacteria. Biosystems Engineering, 96, 129-134.

Ördög, V., Stirk, W. A., Lenobel, R., Bancî́ová, M., Strnad, M., van Staden, J., et al. (2004). Screening microalgae for some potentially useful agricultural and pharmaceutical secondary metabolites. Journal of Applied Phycology, 16, 309-314.

Quintela, A., Almeida, S., Terroso, D., Ferreira da Silva, E., Forjaz, V., \& Rocha, F. (2013). Diatom assemblages of thermal and mineral waters from volcanic environments in São Miguel Island, Azores. Diatom Research, 28, 407-417.

Ramachandra, T. V., Mahapatra, D. M., \& Gordon, R. (2009). Milking diatoms for sustainable energy: biochemical engineering versus gasoline-secreting diatom solar panels. Industrial and Engineering Chemistry Research, 48, 8769-8788

Reisser, W. (2013). Polyextremophilic photoautotrophic eukaryotic algae. In J. Seckbach, A. Oren, \& H. Stan-Lotter (Eds.), Polyextremophile (pp, 567-580). Amsterdam: Springer.

Roeselers, G., Norris, T. B., Castenholz, R. W., Rysgaard, S., Glud, R. N., Kühl, M., et al. (2007). Diversity of phototrophic bacteria in microbial mats from Arctic hot springs (Greenland). Environmental Microbiology, 9, 26-38.

Saitou, N., \& Nei, M. (1987). The neighbor-joining method: a new method for reconstructing phylogenetic trees. Molecular Biology and Evolution, 4, $406-425$.

Sanger, F., Nicklen, S., \& Coulson, A. R. (1977). DNA sequencing with chainterminating inhibitors. Proceedings of the National Academy of Science of the United States of America, 74, 5463-5467.

Schrader, M., Drews, G., Golecki, J. R., \& Weckesser, J. (1981). Isolation and characterization of the sheath from the cyanobacterium Chlorogloeopsis PCC 6912. Microbiology, 128, 267-272.

Singleton, R., \& Amelunxen, R. E. (1973). Proteins from thermophilic microorganisms. Bacteriological Reviews, 37, 3-320.

Stavreva-Veselinovska, S., \& Todorovska, A. (2010). Ecology of the diatomic flora in thermo-mineral springs of Katlanovska Banja in the Republic of Macedonia. Ecologia Balkanica, 2, 1-6.

Stockner, J. G. (1967). Observations of thermophilic algal communities in Mount Rainier and Yellowstone National Parks. Limnology and Oceanography, 12, $13-17$.

Tamura, K., Nei, M., \& Kumar, S. (2004). Prospects for inferring very large phylogenies by using the neighbor-joining method. Proceedings of the National Academy of Science of the United States of America, 101, 11030-11035.

Tamura, K., Stecher, G., Peterson, D., Filipsk, A., \& Kumar, S. (2013). MEGA6: Molecular evolutionary genetics analysis version 6.0. Molecular Biology and Evolution, 30, 2725-2729.

Trukhin, N. V. (1963). Comparative evaluation of occurrence in reservoirs of thermophile strains of Chlorella and Scenedesmus. Mikrobiologiya, 32, 513-520.

Tuchman, M., \& Blinn, W. D. (1979). Comparison of attached algal communities in natural and artificial substrata along a thermal gradient. British Phycological Journal, 14, 243-254. 